\title{
CSA's SFM Program: Market access through sustainable forest management ${ }^{1}$
}

\author{
by Peter J. Johnson² and Teresa M. Borgiel ${ }^{3}$
}

\begin{abstract}
A growing number of national and international buyers are now specifying "certified" forest products in their procurement policies. In response, the Canadian Standards Association (CSA) has worked with a diverse range of stakeholders interested in Sustainable Forest Management in Canada to develop CSA's Sustainable Forest Management (SFM) Program. CSA's SFM Program consists of four distinct, yet inter-related components: CAN/CSA Z809, Canada's National Standard for Sustainable Forest Management; chain of custody for forest products; product marking with CSA International's SFM Mark; and, CSA International's Forest Products Group. When these components are combined they provide a comprehensive, credible, and affordable forest certification and product-marking program. The list of organizations accepting forest products certified through the CSA SFM Program is growing within Canada, the United States and abroad.
\end{abstract}

Key words: Canadian Standards Association (CSA), forest certification, certified forest products, chain of custody, product marking, criteria and indicators

Un nombre croissant d'acheteurs nationaux et internationaux exigent, dans leurs devis d'achat, des produits forestiers certifiés. En réponse à ce phénomène, l'Association canadienne de normalisation (CSA) a travaillé, en collaboration avec un grand nombre de parties intéressées par l'aménagement forestier durable au Canada, à l'élaboration du Programme CSA sur l'aménagement forestier durable. Ce programme se compose de quatre éléments distincts quoique reliés : CAN/CSA-Z809, Norme nationale du Canada relative à l'aménagement forestier durable ; chaîne de suivi des produits forestiers ; marquage des produits au moyen de la marque AFD de CSA International ; groupe des produits forestiers de CSA International. Lorsque ces éléments sont combinés, ils assurent un programme de certification des forêts et de marquage des produits complet, crédible et abordable. La liste des organismes qui acceptent le programme AFD de la CSA comme source de produits forestiers certifiés s'accroît au Canada, aux États-Unis et à l'étranger.

Mots clés : Association canadienne de normalisation (CSA), certification des forêts, produits forestiers certifiés, chaîne de suivi, marquage des produits, critères et indicateurs

\section{Introduction}

During the last two decades forest managers and provincial governments were criticized for their forest management practices, and it was suggested that these practices were not sustainable, nor acceptable for Canadian forests. Despite numerous individual and coordinated efforts by forest owners, regulators and managers to "set the record straight," national and international activists branded Canadian forest management practices as irresponsible.

In 1993 the Canadian Standards Association (CSA) was approached by provincial and federal government agencies and the Canadian forest industry to develop credible sustainable forest management standards for Canada. In 1996 CSA published Canada's National Standards for Sustainable Forest Management (CAN/CSA-Z809-96, A Sustainable Forest Management System: Specifications Document and CAN/CSAZ808-96, A Sustainable Forest Management System: Guidance Document) to elevate the playing field for sustainable forest management in Canada, while providing organizations with an opportunity to demonstrate responsible forest management through third-party certification.

\footnotetext{
${ }^{1}$ Based on a presentation at PaperWeek, Montreal, January 2003.

${ }^{2}$ Manager, CSA International Forest Products Group, Suite 402, 90 Burnhamthorpe Road West, Mississauga, Ontario L5B 3C3. E-mail:peter.johnson@csainternational.org.

${ }^{3}$ Program Co-ordinator, CSA International Forest Products Group, Suite 402, 90 Burnhamthorpe Road West, Mississauga, Ontario L5B 3C3. E-mail: teresa.borgiel@csa-international.org.
}

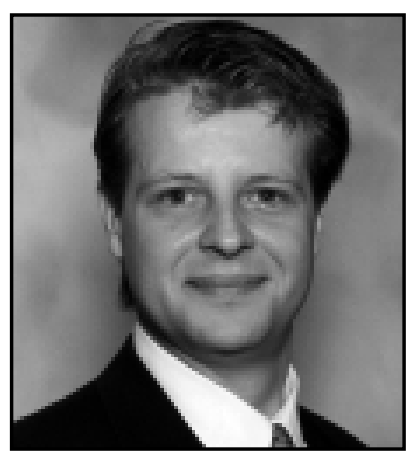

Peter Johnson

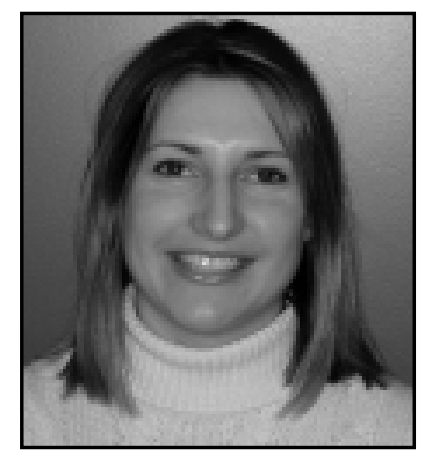

Teresa Borgiel
The interest in forest certification has grown exponentially since in the early 1990s. Today forest certification no longer ends in the forests; it has evolved to the point where buyers have now developed procurement policies that give preference to certified forest products. The following article outlines the merits and importance of forest certification and how CSA's SFM Program can help organizations meet the growing demand for certified forest products.

\section{Why Certified Forest Products and Forest Certification should be of Interest to You}

A growing number of national and international buyers are now specifying "certified" forest products in their procurement policies. There are a number of reasons for this increased 


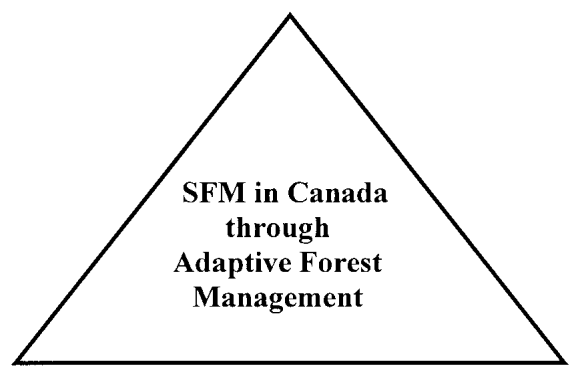

Public Participation Requirements

Management System Requirements

Fig. 1. SFM in Canada through Adaptive Forest Management and the CSA SFM Requirements.

demand. A number of buyers are committed to being social and environmental leaders, wanting to demonstrate this commitment through their purchasing polices and practices. Others are simply responding to the wishes of their stakeholders, while yet other groups are responding to pressure and threats being put on them by environmental activists to "clean up their supply chain" or face the consequences of protests and negative exposure.

This shift in purchasing preference and priority is illustrated globally through the growing list of procurement policies that are acknowledging a preference for certified products. In essence, buyers are looking for assurance that the products they are purchasing have come from certified forests. Regardless of the motivation, a clear trend has emerged in the marketplacebuyers of Canadian forest products are increasingly looking for them to be certified. This trend has been confirmed in the recent IBM Business Consulting Services report, A Greenward Shift in the Market for Forest Products from British Columbia, which concluded "there is clear evidence of a greenward shift in the market for forest products, including those from British Columbia. The shift is real, buyers believe it will continue, and we believe it will have a negative impact on forest regions and producers that do not respond to it" (IMPACS 2003).

Forest managers in Canada have been involved with forest certification for well over a decade. However, the benefits of forest certification have only recently evolved from solid onthe-ground forest management to an opportunity for product differentiation. Buyers and manufacturers are increasingly becoming aware that one way to satisfy all of these interests is through a product label. A product label is a visible means of demonstrating the origin or content of a forest or wood-based product.

Currently, relatively few producers are actively providing certified forest products for the increasing national and international demand. Several companies have made commitments to provide certified products, but a very small number have actually put certified products on the market. There is clearly an opportunity for leaders in forest certification to capitalize on this growing market demand by providing certified forest products.

The window of opportunity for the leaders is closing as many Canadian companies are already executing plans to supply certified forest products to the market. If customer demand and sales opportunities are not large enough drivers to motivate a plan for providing certified forest products there are a few other considerations. First, there is an increasing amount of certified raw mate- rial becoming available across the country. Currently there are over 18 million hectares of forest across Canada certified to CSAZ809 with a continued increase over the next several years. Second, the topics of forest certification and certified forest products are not as overwhelming as they may seem. The knowledge base is increasing at an exponential rate and much of this knowledge is being shared openly. Lastly, the topics of forest certification and certified forest products are not going to go away. These topics have clearly shifted towards the mainstream.

\section{CSA's SFM Program}

CSA was established in 1919 and has a long and rich history rooted in the development of consensus-based standards. Consumer products certified through CSA International have had a positive influence on people around the world for over 50 years. CSA's Mark appears on billions of consumer products, from hockey and bicycle helmets to electrical appliances. All of which have helped CSA work towards it's mission of Making Standards Work for People and Business. It is for these reasons that CSA has worked with a diverse range of stakeholders interested in sustainable forest management in Canada to develop CSA's Sustainable Forest Management Program.

CSA's SFM Program consists of four distinct yet inter-related components: CAN/CSA Z809, Canada's National Standard for Sustainable Forest Management; chain of custody for forest products; product marking with CSA International's SFM Mark; and, CSA International's Forest Products Group. When these components are combined they provide a comprehensive, credible, and affordable forest certification and product-marking program.

\section{CAN/CSA-Z809 - Canada's National Stan- dard for Sustainable Forest Management}

In 1993 CSA was approached by a number of proponents to develop national SFM standards for Canada. According to CSA standards development requirements, an SFM Technical Committee (TC) was established to write the standards. The CSA SFM TC consisted of a balanced matrix from four chambers: Academia/Professional/Practitioner; General Interest/Environmental Groups; Government/Regulatory Authority; and, Business Interest. In 1996 the SFM TC voted unanimously to accept the Standards, CAN/CSA Z809-96 (requirements) and CAN/CSA Z808-96 (guidance) and in 
October of the same year CSA SFM Standards were approved and published as National Standards of Canada. The CAN/CSAZ809 Standard is based on the international Helsinki and Montreal processes and incorporates Canada's own national SFM criteria which were developed by the Canadian Council of Forest Ministers (CCFM 1995, 1997, 2000). In addition, the CAN/CSA-Z809 Standard is the only SFM standard in North America to be developed according to an internationally recognized and accredited standards development process.

The uptake of the 1996 version of CAN/CSA-Z809 was relatively slow due to the high demands and expectations set by the standard. However, by the end of 200214.4 million hectares of forests in Canada were certified to CAN/CSA-Z80996 (Canadian Sustainable Forestry Certification Coalition 2002a).

All National Standards of Canada are required to undergo a mandatory five-year review. In December 2002 CSA completed an 18-month review of both CAN/CSA-Z809-96 and CAN/CSA-Z808-96, which included public consultation and public review periods. The purpose of the mandatory review was to build on new and current research, implementation experience and to continually improve the content and applicability of the Standard. In July 2003, the revised version of the Standard, CSA-Z809-02 was unanimously approved by the CSA SFM TC, and was approved by the Standards Council of Canada as Canada's National Standard for Sustainable Forest Management. Currently, there are 18 million hectares of Canadian forests certified to CAN/CSA-Z809 (Canadian Sustainable Forestry Certification Coalition 2003b).

A number of key lessons were learned through the Standard review process. Specifically, the acknowledgement that adaptive forest management should continue to be the basis of SFM in Canada, and in order to link adaptive forest management to forest certification, three key requirements are necessary: Performance Requirements, Public Participation Requirements and System Requirements (Fig. 1). These three requirements are referred to as the CSA SFM Requirements in the CSA-Z80902 Standard.

\section{Performance requirements}

The Performance Requirements of both the 1996 and 2002 versions of the CSA Z809 Standard are based on the Canadian Council of Forest Ministers (CCFM) SFM criteria, elements and indicators. It is believed that this is the best set of broadly accepted Canadian forest values. In the set, there are six criteria representing high-order forest values and several related elements, each representing a specific feature of the criterion with which it is associated. A critical underlying principle of the CSA-Z809 Standard is that the starting point for performance is meeting the applicable legal requirements. One of the best methods of managing forests beyond legal requirements is in the application of the CCFM Criteria through a rigorous public participation process at the forest level.

In the CAN/CSA Z809-96 Standard, adoption of the CCFM SFM criteria and elements as a framework for forest value identification provided vital links between local level SFM and national and provincial-scale forest policy, as well as a strong measure of consistency in the identification of local forest values across Canada. In CSA Z809-02, the CCFM SFM criteria have been adopted verbatim, but the elements (formerly critical elements) have been revised to reflect the need for meaningful application at the defined forest area (DFA) level and are now called CSA SFM Elements. The CCFM document states that many of the elements do not apply at the local forest level; hence, by modifying the CCFM elements, CSA Z809-02 is not diverging from the concept of the CCFM elements, but rather ensuring their applicability at the DFA level.

The CSA Z809-02 Standard addresses the wide range of issues related to SFM through performance-based actions in three specific ways. First, the mandatory CCFM Criteria and related CSA SFM Elements must be addressed through the public participation and value, objective, indicator and target (VOIT) setting processes and applied on the DFA. For example, CSA SFM Element 1.4 Protected Areas and Sites of Special Biological Significance requires an organization to respect protected areas and identify sites of biological significance within the DFA and implement management strategies appropriate to their long-term maintenance. These strategies are defined through the establishment of associated values and the application of on-the-ground objectives, indicators and targets related to protected area and sites of biological significance.

Second, section 5.4 (vi) of the Standard allows for any value or issue, related to SFM on the DFA, to be brought forward by any individual or interested party. These issues must be addressed through the public participation process through one or several methods provided in the standard.

Lastly, CSA Z809-02 contains a mandatory performance matrix (Annex C) which requires the organization to clearly define, set and record the DFA-specific performance requirements. This matrix must be completed through the public participation process, and describe the DFA level application of the CCFM Criterion, CSA SFM Elements, values, objectives, indicators, targets, basis for the targets, legal requirements, means of achieving the objectives and targets, monitoring and measurement requirements and levels of acceptable variance. This matrix will become a key vehicle for addressing and communicating the organization's SFM performance in a transparent, publicly accessible manner.

\section{Public participation requirements}

Given that the vast majority of Canada's forested lands are publicly owned, the CSA SFM Standard has always had a rigorous public participation process as a key requirement. Since publishing the CSA SFM Standard in 1996, the scope and rigour of government regulated public input processes for forest management planning in Canada continues to improve. Many organizations implementing the CAN/CSA Z809-96 Standard found it challenging to implement a separate public participation process to specifically meet the CAN/CSA-Z809-96 requirements on top of an existing comprehensive regulated public input process. Hence, the public participation process requirements in CSA-Z809-02 have been revised to clarify that the public participation requirements can be met by either initiating a new process, building on an existing process, or by reviving a previous public participation process. For example, a provincially required public consultation process may be modified to address the CSA SFM Requirements, or a separate public participation process to address the CSA SFM Requirements may be initiated. Whichever approach is selected, all of the Public Participation Requirements must be met. As well, the public participation process requires an organization implementing the Standard to respect and apply national criteria for SFM at the local level (through the CCFM Criteria and CSA 


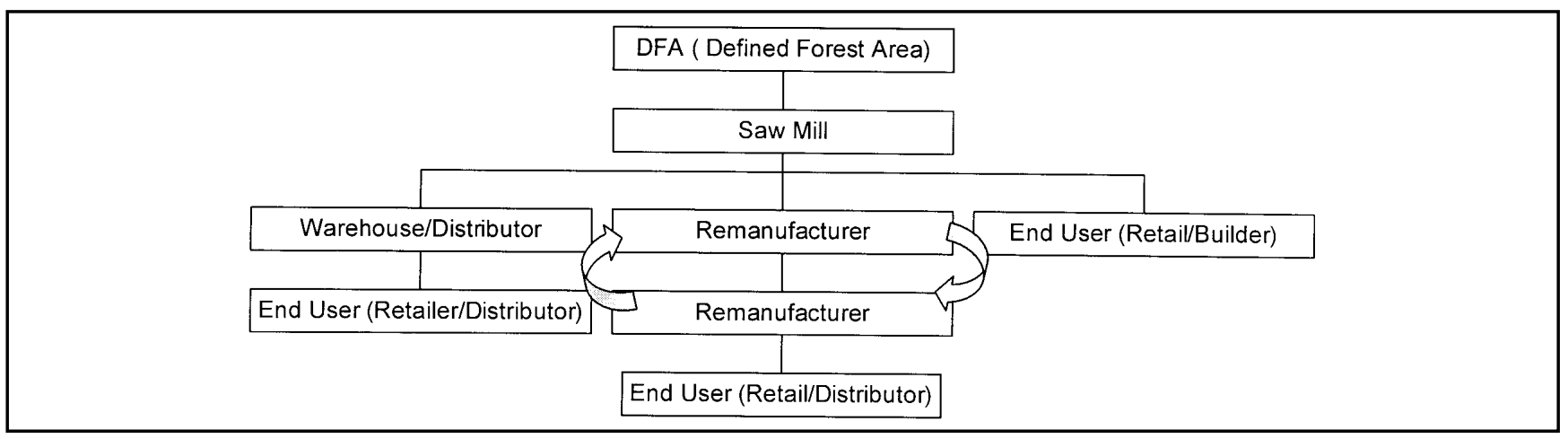

Fig. 2. Chain of custody for forest products.

SFM Elements), as well as address any other local issues or values. Furthermore, the public participation process has a much stronger role in identifying and determining key aspects the public participation process will address and how decisions will be made.

\section{System requirements}

Over the past five years it has become clear to forest managers across the country that management systems such as ISO 14001(CSA 1996c) are very powerful tools for a variety of purposes. Recognizing this, the CSA-Z809-02 Standard is consistent with the ISO 14001 Standard. It is essential to have a management system that can help assure the fulfillment of all the CSA SFM Requirements year after year. The management system requirements are viewed as the vehicle to deliver both the Public Participation and Performance Requirements in a systematic and predictable manner. This will also help drive adaptive forest management and continual improvement.

Additional enhancements to the CSA-Z809-02 Standard focus on formatting and accessibility. In response to feedback from users of the CSA SFM Standards CAN/CSA-Z808-96 (guidance) and CAN/CSA-Z809-96 (specifications) have been combined into one document, incorporating both the guidance and requirements into CSA-Z809-02. Recognizing the importance of improved access to the Standard, the 2002 version of the Z809 Standard, is now available at no cost from CSA. It is in electronic format, downloadable at:

http://certifiedwood.csa.ca.

\section{Chain of Custody}

The remaining components to CSA's SFM Program were created in response to requests from a variety of stakeholders to link CAN/CSA-Z809 to forest products and consumers. Once assurance is provided that forests are being managed according to established principles of sustainable forest management, the next voluntary steps are the recognition and promotion of forest products that have originated from a forest area certified to CSA-Z809.

In July 2001, CSA International created the Forest Products Marking Program. Under this program CSA International offers organizations an opportunity to further demonstrate their commitment to SFM through a chain of custody and product mark.

The concept of chain of custody is relatively new to the forest industry but it has been a critical element in other sectors for several years. In its simplest form, chain of custody is the traceability and accountability of forest products throughout the supply chain. Chain of custody is a method of tracking an end product or wood-based raw material back to its certified forest of origin, and is a tool to provide customers with assurance that products they are purchasing have originated from a certified forest (Fig. 2).

In the manufacturing of forest products and wood-based products there may be one or several stages in the transformation process from tree to final product. The ownership of the certified product may change several times throughout the transformation process. These transformation or ownership changes are referred to as "links" in the chain of custody from forest to consumer. Examples of these links may include: defined forest areas; modes of transportation (carriers such as trucks, ships, booms and rail); manufacturing facilities (primary, secondary, re-manufacturing, value-added) that use certified forest products; warehouses, stockyards and reloads that repackage certified forest products; and, traders/brokers who do not have physical contact with the forest products, but obtain ownership for a period of time.

The scope of a chain of custody will be defined by the implementing organization. Generally, it will cover the certified forest products from the point at which the organization takes ownership or control to the point at which they are delivered to the next "link" in the chain, or to the end consumer.

Certified forest products can take many forms. Examples include, but are not limited to the following:

- traditional forest products such as unprocessed logs, lumber or plywood;

- by-products or residues that arise from manufacturing or remanufacturing processes such as chips and sawdust;

- products to be re-manufactured such as pulp and lumber;

- products for the end consumer such as lumber;

- composite products such as paper, doors, window frames, furniture;

- non-traditional forest products such as blueberries, mushrooms or Christmas trees.

The CSA's chain of custody requirements are the most rigorous and credible in the marketplace today. The requirements are outlined in CSA PLUS 1163: Chain of Custody for Forest Products Originating from a Defined Forest Area Registered to CAN/CSA-Z809 (CSA 2001). In addition to critical requirements such as verification of the origin of raw materials and inventory monitoring and control, the CSA chain of 
custody also includes requirements for environmental management and product claims. The CSA chain of custody program is the only chain of custody scheme to include these requirements, which are based on the belief that certified forest products should be produced by facilities that are environmentally responsible.

The chain of custody program is managed and delivered through CSA International's Forest Products Group. Currently, 43 chain of custody certificates have been issued covering 71 sites with additional certifications underway. Once certified to CSA PLUS 1163 an organization may choose to apply CSA's new SFM Mark on their product.

\section{CSA International's SFM Product Mark}

In 2001, CSA International created a new product mark for companies that are manufacturing forest products originating from a forest certified to CSA-Z809 and are tracked through a certified CSA PLUS 1163 chain of custody. The CSA SFM Mark features both coniferous and deciduous trees and the familiar CSA insignia.

CSA International's Forest Products Marking Program has brought together decades of product marking knowledge and experience and combined it with sustainable forest management. The CSA SFM Mark demonstrates to customers that forest products bearing this Mark have originated from a forest certified to CSA-Z809 and have been verified through an independent chain of custody audit. This creates a powerful opportunity for both suppliers and buyers of forest products to demonstrate and communicate their commitment to sustainable forest management.

Within CSA International's Forest Products Marking Program there are three product marking options. These options are based on how the inventories of certified forest products are managed.

Option 1: Minimum Average Percentage System for Solid Wood

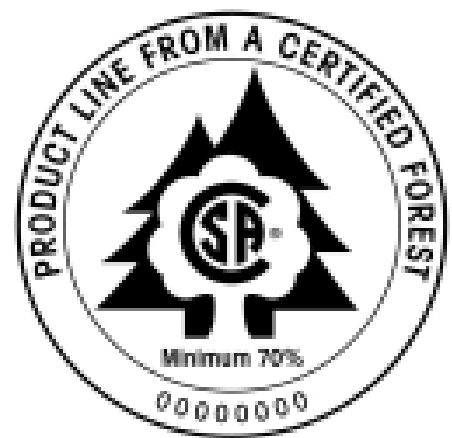

The minimum average percentage system approach is based on the premise that the total batch of products can be labelled with the CSA SFM Mark when the amount of certified (originating from a forest certified to Z809) wood-based raw material in the input batch meets or exceeds the set minimum average threshold. In order to apply the CSA SFM Mark the minimum average input is $70 \%$ (by volume or by weight) of certified (originating from a forest certified to Z809) wood-based raw material. In addition, none of the wood-based raw material (including the remaining input percentage of wood-based raw material) shall have come from controversial sources. This Mark appears on the product and/or the packaging.
Option 2: Minimum Average Percentage System for Composite Products

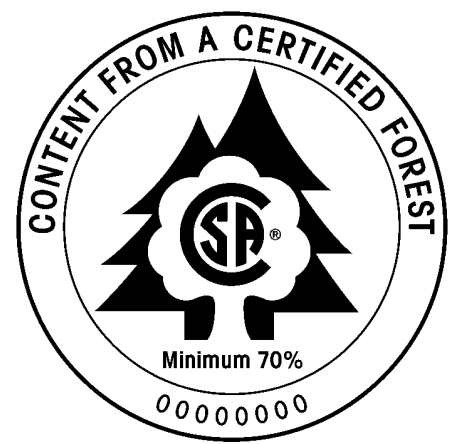

The minimum average percentage system approach is based on the premise that the total batch of products can be labelled with the CSA SFM Mark when the amount of certified (originating from a forest certified to Z809) wood-based raw material in the input batch meets or exceeds the set minimum average threshold. In order to apply the CSA SFM Mark the minimum average input is $70 \%$ (by volume or by weight) of certified (originating from a forest certified to Z809) wood-based raw material. In addition, none of the wood-based raw material (including the remaining input percentage of wood-based raw material) shall have come from controversial sources. This Mark appears on the product and/or the packaging.

\section{Option 3: Physical Separation (Segregation)}

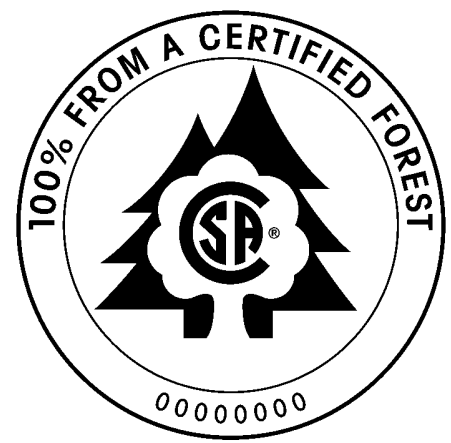

In this approach, certified wood, wood raw materials, and wood products are received and clearly marked or physically segregated or otherwise identified as certified (originating from a forest certified to CSA Z809) and remain clearly identifiable as certified throughout transportation, handling, processing, manufacturing or remanufacturing process(s). This Mark appears on the product and/or the packaging.

Currently, three sites are licensed to apply the CSA SFM Mark, Canfor's Grande Prairie sawmill in Alberta (Fig. 3), B.W Creative Wood Industries Ltd. - a remanufacturer based in Maple Ridge, British Columbia and Visscher Lumber-a valueadded sawmill in Chilliwack, British Columbia.

\section{CSA International's Forest Products Group}

The last component of the CSA SFM Program is the creation of CSA International's Forest Products Group. This Group is responsible for the management and delivery of the Forest Products Marking Program and for assuring the integrity of the CSA SFM Mark. The role of the Forest Products Group is to be the voice of the CSA 


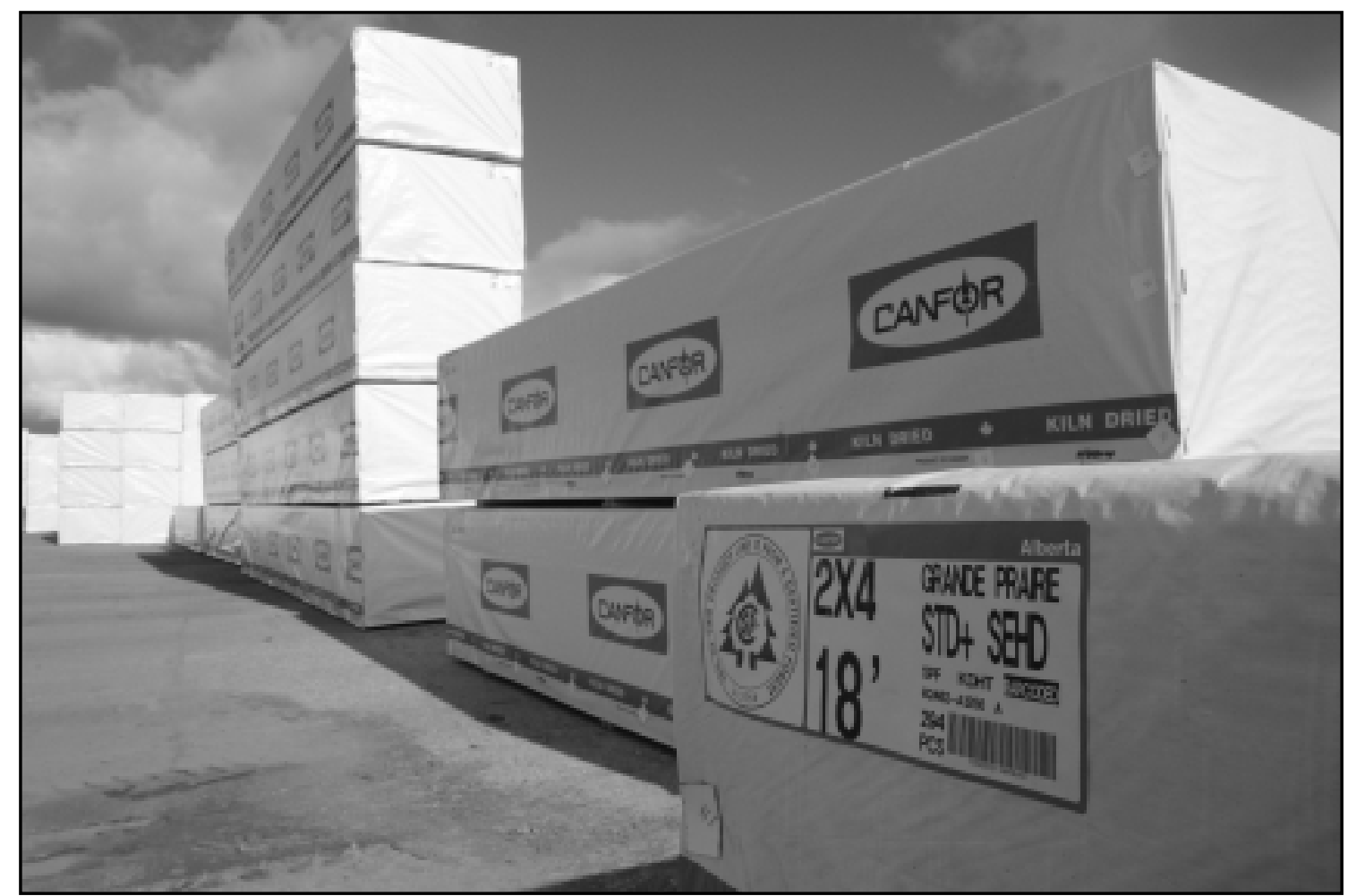

Fig. 3. CSA certified lumber, Canfor Sawmill Grande Prairie, Alberta. Published with permission from Canfor.

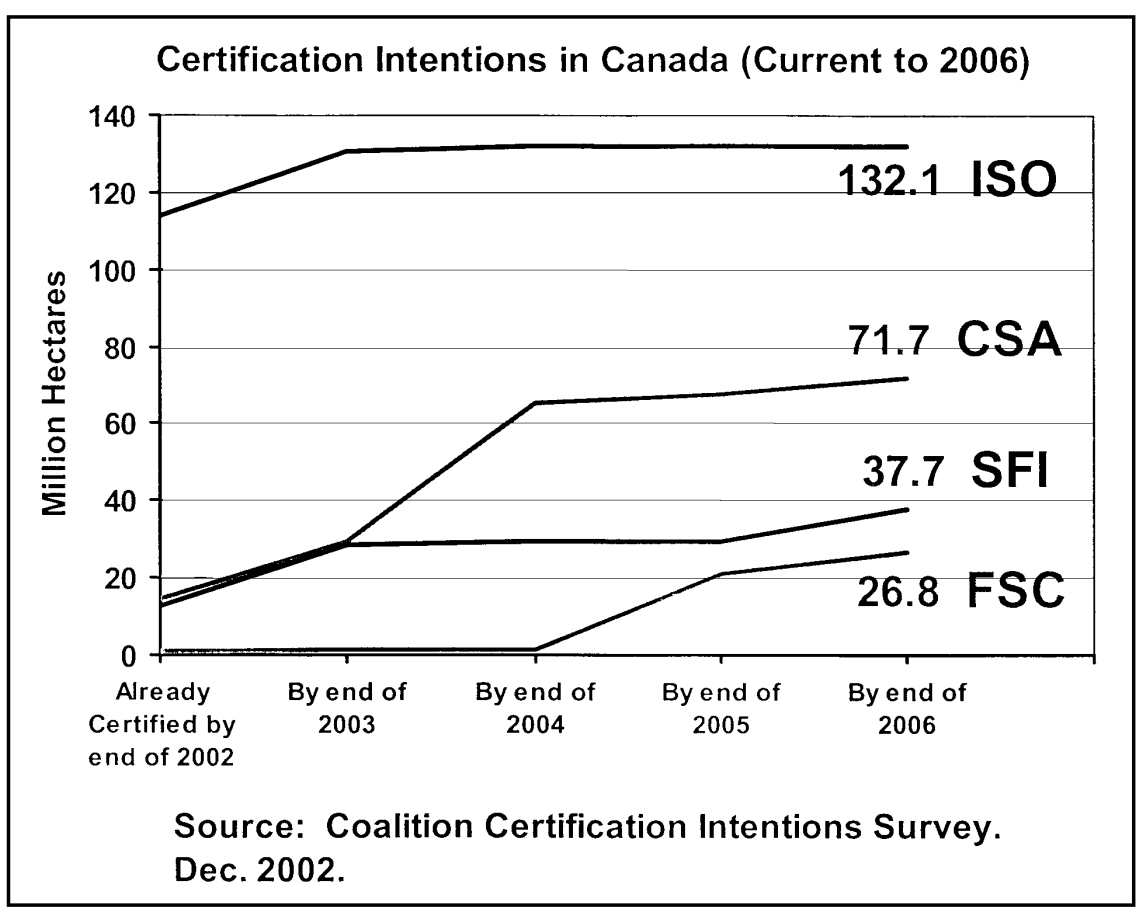

Fig. 4. Forest certification intentions in Canada.

SFM Program, and actively promote the Program nationally and internationally throughout the forest products chain, from forest managers through to the end consumers.

\section{The European Connection}

CSA International's Forest Products Group is Canada's Member Body to the Pan European Forest Certification (PEFC
Council). PEFC is a framework for the mutual recognition of credible national or regional forest certification schemes, which have been developed to meet internationally recognized requirements for sustainable forest management. Organizations interested in PEFC certification or product marking are able to access these opportunities through CSA International's Forest Products Group. 


\section{Who is Accepting CSA Forest Certifications?}

The list of organizations accepting the CSA SFM Program as a source of certified forest products is growing within Canada, the United States and abroad. Major buyers such as Home Hardware, Centex Homes, Pella Corporation and Hallmark Cards are accepting the CSA SFM Program. CSA International's Forest Products Group regularly meets with buyers, influencers and organizations to generate their support for the CSA SFM Program.

\section{The Future}

The importance of forest certification and certified forest products will increase in the future as forests managers and producers of forest products continue to become proactive about sustainable forest management certification and buyers increasingly specify certified forest products. According to a recent study, it is forecasted that the number of hectares certified to CSA Z809 in Canada is going to increase from 14.4 million hectares in 2002 to almost 72 million hectares by the end of 2006 (Fig. 4) (Canadian Sustainable Forestry Certification Coalition 2002b). This dramatic increase suggests that CSA and the stakeholders it works with are concerned about sustainable forest management in Canada, and have developed a credible and usable forest certification program for Canadian forests. The CSA SFM Program will continue to raise the bar on sustainable forest management in Canada and provide market access through chain of custody and product marking.

For more information about CSA's SFM Program please contact CSA International's Forest Products Group at 1-866CSA WOOD or visit our Web site at http://certifiedwood.csa.ca. Documents related to the CSA SFM Program can be simply downloaded from our Web site.

\section{References}

CCFM (Canadian Council of Forest Ministers) 1995. Defining Sustainable Forest Management: A Canadian Approach to Criteria and Indicators, Canadian Forest Service, Natural Resources Canada.
CCFM (Canadian Council of Forest Ministers) 1997. Criteria and Indicators of Sustainable Forest Management in Canada, Technical Report, 1997.

CCFM (Canadian Council of Forest Ministers) 2000. Criteria and Indicators of Sustainable Forest Management in Canada, National Status, 2000.

Canadian Standards Association (CSA) 1996a. CAN/CSA-Z80896 A Sustainable Forest Management System: Guidance Document. Canadian Standards Association, Toronto, Ontario, Canada. 33 p. Canadian Standards Association (CSA) 1996b. CAN/CSA-Z80996 A Sustainable Forest Management System: Specifications Document. Canadian Standards Association, Toronto, Ontario, Canada. 12 p.

Canadian Standards Association (CSA) 1996c. CAN/CSA-ISO 14001-96 Environmental Management Systems - Specifications With Guidance For Use. Canadian Standards Association, Toronto, Ontario, Canada.

Canadian Standards Association (CSA) 2001. CSA PLUS 1163: Chain Of Custody For Forest Products Originating From A Defined Forest Area Registered To CAN/CSA-Z809. Canadian Standards Association, Toronto, Ontario, Canada. 7 p.

Canadian Standards Association (CSA) 2002. CSA-Z809-02 Sustainable forest management: requirements and guidance. Canadian Standards Association, Toronto, Ontario, Canada. 51 p.

Canadian Sustainable Forestry Certification Coalition. 2002a. Canadian Forest Management Certification Status Report, Canada-Wide Report, December 21, 2002.

Canadian Sustainable Forestry Coalition. 2002b. Canadian Sustainable Forestry Certification Coalition Bulletin, December 31, 2002.

Canadian Sustainable Forestry Certification Coalition. 2003. Canadian Forest Management Certification Status Report, CanadaWide Report, September 7, 2003.

IMPACS. 2003. A Greenward Shift in the Market for Forest Products From British Columbia. A report commissioned by IMPACS and prepared by IBM Business Consulting Services, IBM Corporation, IBM Business Consulting Services, Toronto, Ontario, Canada. 53 p. 